\title{
REPELLENCY AND TOXICITY OF FOUR ESSENTIAL OILS TO SITOPHILUS ORYZAE L. (COLEOPTERA: CURCULIONIDAE)
}

\author{
P.A. PARANAGAMA ${ }^{* 1}$, K.H.T. ABEYSEKERA ${ }^{1}$, L. NUGALIYADDE ${ }^{2}$, and K.P. \\ ABEYWICKRAMA ${ }^{3}$ \\ ${ }^{1}$ Department of Chemistry, University of Kelaniya, Kelaniya. \\ ${ }^{2}$ Entomology Division, Rice Research and Development Institute, Bathalagoda, \\ Ibbagamuwa. \\ ${ }^{3}$ Department of Botany, University of Kelaniya, Kelaniya.
}

(Received: 07 April 2003 ; accepted: 01 December 2003)

\begin{abstract}
The essential oils of the leaves of Cymbopogon citratus, Cymbopogon nardus, Cinnamomum zeylanicum and rhizome of Alpinia calcarata grown in Sri Lanka were tested for repellent activity, fumigant toxicity and contact toxicity against Sitophilus oryzae. The major components of the essential oils were geraniol in C. nardus, citral $a$ and $b$ in C. citratus, eugenol in C. zeylanicum and 1,8-cineol in A. calcarata. In a dual choice repellency test, repellency to $S$. oryzae increased with increasing dose of each oil except $C$. zeylanicum at a dose of $1 \mathrm{mg}$. Cymbopogon citratus was the most toxic oil to $S$. oryzae during the fumigant toxicity test with an $\mathrm{LC}_{50}$ value of 0:035 $\mathrm{g} / \mathrm{l}$. Adults of $S$. oryzae were equally susceptible to the fumigant toxicity of $C$. nardus and C. zeylanicum at $0.1 \mathrm{~g} / 1$ level. Furthermore, $S$. oryzae adults were tolerant to the contact $\left(0.15 \mathrm{~g} / \mathrm{m}^{2}\right)$ and fumigant $(0.1 \mathrm{~g} / \mathrm{l})$ activities of $A$. calcarata oil and the mortality of the test insects was not significantly different from the controls.
\end{abstract}

Key words: essential oils, rice, Sitophilus oryzae, stored grain

\section{INTRODUCTION}

Sitophilus oryzae L. is one of the major pests of stored cereals and the predominant pest of stored rice. The control of insect pests in storage is largely based on synthetic insecticides and fumigants (pirimiphos methyl and phosphine) which have led to the development of insecticide resistant strains, increasing cost of application, lethal effects on non-target organisms in addition to direct toxicity to users. ${ }^{1-3}$ Thus repellents, fumigants, feeding deterrents and insecticides of natural origin obtained from the respective regions are rational alternatives to synthetic insecticides. ${ }^{4,5}$ Certain essential oils, on account of their volatile nature and other traditional uses, offer possibilities for their use as effective repellents and toxicants against stored grain pests..$^{6-8}$ In many Asian and African countries it is an age-old practice to mix plant parts with grain to manage stored grain pests. ${ }^{9,10}$ Mixing of plant leaves of Vitex negundo, Ocimum sanctum, Eucalyptus terreticornis and Citrus sp., which contain essential oils with stored paddy at $1 \%(\mathrm{w} / \mathrm{w})$, effectively controlled primary and secondary insect pests including S. oryzae. ${ }^{11}$ The bark extract of Melia

* Corresponding author 
toosendan was found to be repellent and toxic to $S$. oryzae. ${ }^{8}$ The essential oil from Labiatae sp. at concentrations varying from 1.4 to $4.5 \mu \mathrm{l} / \mathrm{l}$ induced $90 \%$ mortality in stored product beetles including $S$. oryzae after $24 \mathrm{~h}$ of fumigation. ${ }^{12}$ Bioactivity of essential oils of Evodia rutaecarpa, nutmeg seeds and Elletaria cardamomum have been reported to have repellent and toxic activities against $S$. zeamais. ${ }^{5 \cdot 7}$

In Sri Lanka, farmers use essential oil-bearing plants, which release terpenes for the control of stored grain pests. Cymbopogon nardus Rendle, Cymbopogon citratus (DC.) Stapf., Cinnamomum zeylanicum Blume and Alpinia calcarata Rosc. are some of the essential oil-bearing plants grown in Sri Lanka.

C. citratus (lemongrass) and C. nardus (citronella) belong to the family Poaceae (Graminae) and yield essential oils which are mainly used in the spice and essential oil industry. $C$. citratus yields an essential oil with $>70 \%$ of citral $a$ and $b$. The essential oil is used to combat mosquitoes and houseflies at a dose of 30 and $7.5 \mu \mathrm{g}$ per insect. ${ }^{13}$ Powdered C. citratus has been used as a repellent against Callasobruchus sp. ${ }^{14}$ Geraniol (19\%) is the major component of the essential oil of C. nardus. ${ }^{15}$ The essential oil of $C$. nardus has been shown to have a repellent activity against Tribolium castaneum, Sitotroga cerealella, Callasobruchus chinensis and many other stored grain insect pests. ${ }^{16}$ The essential oil of C. nardus was found to have toxic and repellent actions on C. maculatus. ${ }^{17,18}$ C. zeylanicum Blume (Lauraceae) (cinnamon) leaf oil contains $77 \%$ of eugenol. ${ }^{19}$ Eugenol was shown to have contact toxicity against $S$. zeamais $\left(\mathrm{LD}_{50} 30 \mu \mathrm{g} / \mathrm{mg}\right.$ insect). ${ }^{20} A$. calcarata Rosc. (Zingiberaceae) (S. Heenaraththa) rhizomes are used in indigenous medicine. Tewari et al. have reported the presence of $42 \%$ of 1,8-cineol in the rhizome essential oil and repellent activity of the essential oil was tested against Periplanata americana. ${ }^{21,22}$ This study was undertaken to evaluate the bioefficacy of the essential oils from the leaves of $C$. citratus, $C$. nardus, $C$. zeylanicum and rhizomes of $A$. calcarata on $S$. oryzae with a view to develop an environmentally safer, effective and economical control method.

\section{METHODS AND MATERIALS}

Insects: $S$. oryzae was obtained from laboratory cultures maintained at $28 \pm 3{ }^{\circ} \mathrm{C}$, $70-80 \%$ r.h. and a photoperiod of 12:12 (L:D). One-week-old adult insects were used for all the bioassays.

Essential oils: The essential oils of C. zeylanicum, C. nardus and C. citratus leaves were purchased from the Industrial Technology Institute, Hendrik and Sons and EOAS Organics Ltd., Colombo, respectively. Rhizomes of A. calcarata were cut into pieces, air-dried and steam distillated for $3 \mathrm{~h}$. The distillate was extracted into dichloromethane and concentrated on a rotary evaporator ( $\mathrm{R}-114$ and B-180, BÜCHI, Labortechnik AG, Flawil, Switzerland) at $35{ }^{\circ} \mathrm{C}$. Remaining solvent was evaporated under a dry nitrogen stream and residue stored at $4-5^{\circ} \mathrm{C}$ in sealed 
glass vials. Different dilutions of the essential oils were made using ethanol in all the experiments.

Gas chromatographic (GC) analysis of the essential oils: The chemical constituents of each essential oil used for bioassays in the present study were analyzed on a GC having the following specifications (HP5890 series II chromatograph, Hewlett Packard, Palo Alto, CA, USA with FID and DBwax capillary column, J \& W Scientific, Folsom, CA, USA, $30 \mathrm{~m} \times 0.25 \mathrm{~mm} ; 0.25 \mu \mathrm{m}$ film thickness). The column was programmed as follows; $40{ }^{\circ} \mathrm{C}(0 \mathrm{~min}$. $), 40^{\circ} \mathrm{C}$ to $210^{\circ} \mathrm{C}$ at $5{ }^{\circ} \mathrm{C} / \mathrm{min}, 210^{\circ} \mathrm{C}(10$ min.) with Helium carrier gas $(1 \mathrm{ml} / \mathrm{min})$. The injector and detector temperatures were $220{ }^{\circ} \mathrm{C}$ and $270{ }^{\circ} \mathrm{C}$ respectively, and $1 \mu \mathrm{l}$ of the oil solution in $\mathrm{CH}_{2} \mathrm{Cl}_{2}(2 \mathrm{mg} /$ $\mathrm{ml}$ ) was injected and the constituents were analysed and compared with published data. ${ }^{15,19}$

Repellent activity: A "Y" shaped olfactometer with 3 connected glass tubes $(10 \mathrm{~cm}$ long, $1 \mathrm{~cm}$ diameter) with an opening at the intersection of the 3 arms for the vacuum pump was used as the olfactometer. The opening on the intersection of the arms facilitated the air circulation in the olfactometer. ${ }^{23}$ The ends of the two tubes of the olfactometer were connected with perforated, plastic, transparent, wide mouthed bottles $(250 \mathrm{ml})$ through the lids and the other end of the tube was used to introduce insects. Two Whatman no. 1 filter papers $(2.5 \mathrm{~cm} \times 2.5 \mathrm{~cm})$, one treated with a known amount of essential oil and the other treated with equal amount of ethanol were hung separately, after air-drying for 10 minutes, in the middle of the bottles connected to the two tubes using metal wires. The olfactometer was placed horizontally on a white background in daylight. After switching on the vacuum pump, ten test insects were introduced into the olfactometer. The number of insects that moved into the essential oil treated and ethanol treated bottles within 30 minutes were recorded. Five doses of $C$. citratus $(10-150 \mathrm{mg}), \mathrm{C}$. nardus $(0.5-7.5$ $\mathrm{mg})$, C. zeylanicum $(1.0-10.0 \mathrm{mg})$ and $A$. calcarata $(0.5-7.5 \mathrm{mg})$ were tested separately and each dose was replicated 5 times. Placement of the essential oil treated and the ethanol treated filter papers were interchanged randomly in subsequent replicates. At each trial, the olfactometer was washed thoroughly with a detergent and dried in an oven. This assay was carried out between 07.00 and $10.00 \mathrm{~h}$. The mean number of insects that responded to the two treatments at each dose was compared by Chi Square test.

Fumigant toxicity: Whatman no. 1 filter paper discs (1 cm diameter), each impregnated with essential oils dissolved in ethanol to give concentrations of 20.0 , $30.0,40.0,50.0,60.0$ and $100.0 \mathrm{mg} / \mathrm{l}$ air for C. citratus, 10.0, 50.0, 100.0, 150.0 and $200.0 \mathrm{mg} / \mathrm{l}$ air for $C$. nardus, 50.0, 100.0, 250.0, 500.0 and $750.0 \mathrm{mg} / \mathrm{l}$ air for $C$. zeylanicum and 100.0, 200.0,300.0, 400.0 and $500.0 \mathrm{mg} / \mathrm{l}$ air for A. calcarata were used separately. Each disc was placed on the underside of the screw cap of each glass bottle $(7 \mathrm{ml})$ and the solvent was allowed to evaporate for $10 \mathrm{~min}$. The neck of each bottle containing 10 insects was blocked with metal mesh ( $1 \mathrm{~cm}$ diameter). 
The bottles were incubated at $28 \pm 3^{\circ} \mathrm{C}$ for $48 \mathrm{~h}$ in the dark. A similar procedure was carried out with ethanol and untreated samples were used as the control. Each treatment and control was replicated 5 times. At the end of the $48 \mathrm{~h}$ fumigant exposure period mortality was recorded. The mean mortality for each essential oil concentration was compared using ANOVA and Tukey's pair-wise comparison test. The LC50 values were determined by Probit Analysis using a computer package.

Contact toxicity: Glass bottles similar to those used in fumigant toxicity test were used (20 $\mathrm{cm}^{2}$ area of the inner surface). Different doses of the test essential oils dissolved in ethanol were applied onto the inner surface of the bottles to give the concentrations of $3.7,7.5,10.0,15.0,20.0 \mu \mathrm{g} / \mathrm{cm}^{2}$ of $C$. citratus, $6.0,9.0,12.0,15.0$, $20.0 \mu \mathrm{g} / \mathrm{cm}^{2}$ of C. nardus, $2.5,5.0,7.5,10.0,12.5,15.0 \mu \mathrm{g} / \mathrm{cm}^{2}$ of C. zeylanicum and $15.0,30.0,45.0,60.0,75.0,90.0 \mu \mathrm{g} / \mathrm{cm}^{2}$ of A. calcarata. Ethanol was evaporated under a dry $\mathrm{N}_{2}$ stream and 10 insects were introduced into each bottle. There after the procedure followed was similar to the fumigant toxicity assay.

Fumigant and contact toxicity tests were carried out with Actellic ${ }^{\circledR}$ (Pirimiphos methyl) as the synthetic pesticide and the LC50 values for comparison were obtained using probit analysis.

\section{RESULTS}

The main constituents identified by the respective relative retention times in the essential oils are listed in Table 1 . Citral $a$ and $b(77.8 \%)$ were the main volatiles in C. citratus. Geraniol and limonene in C. nardus and eugenol in C. zeylanicum leaf were the major constituents of the respective oil. The essential oil of A. calcarata contained 1,8-cineole as the major constituent and the camphoraceous odour of the essential oil was due to 1,8 -cineol and camphor.

S. oryzae were unable to recognize the oil treated bottle when given a choice between the essential oil treatment and control at 10 and $25 \mathrm{mg}$ of C. citratus, 0.5 $\mathrm{mg}$ of $C$. nardus and 0.5 and $1.0 \mathrm{mg}$ of $A$. calcarata (Table 2). However at higher doses of each oil, a significant number of test insects moved away from the treated bottles. Although, at the dose of $1.0 \mathrm{mg}$ of C. zeylanicum, significantly higher number of insects moved into the treated bottle compared to the control, the results indicate that C. zeylanicum oil acts as a repellent at higher doses (> $5 \mathrm{mg})$.

Table 3 shows the fumigant and contact effects of each essential oil at $100.0 \mathrm{mg} / \mathrm{l}$ and $15.0 \mu \mathrm{g} / \mathrm{cm}^{2}$ concentrations, respectively. $S$. oryzae, when exposed to fumigants of each essential oil at $100.0 \mathrm{mg} / \mathrm{l}$ concentration the highest susceptibility was shown for $C$. citratus oil. At similar concentrations, $C$. nardus and C. zeylanicum oils were not significantly different in their fumigant activitiy $(\mathrm{p}<0.05)$. The essential oil of $A$. calcarata showed the lowest fumigant activity and the response of insects was not significantly different from the control and the 
ethanol treated samples ( $\mathrm{p}<0.05$ ). The lowest and the highest $\mathrm{LC}_{50}$ values of $35 \mathrm{mg} /$ 1 and $367 \mathrm{mg} / \mathrm{l}$ were obtained for C. citratus and A. calcarata respectively during the fumigant toxicity assay.

Table 1: Composition of major constituents of essential oils found in four plant species.

\begin{tabular}{ll}
\hline Plant species & Major constituents $(\%)^{*}$ \\
\hline Cymbopogon citratus & citral $a(46.2)$ \\
& citral $b(31.6)$ \\
& geraniol (3.6) \\
& geranyl acetate (1.3) \\
Cymbopogon nardus & geraniol (17.7) \\
& limonene (9.8) \\
& camphene (8.6) \\
& barneol (7.5) \\
& methyl isoeugenol (6.8) \\
& citronellal (4.3) \\
& eugenol (74.2) \\
& $\beta$-caryphyllene (3.5) \\
Cinnamomum zeylanicum & benzyl benzoate (2.8) \\
& cinnamaldehyde (2.7) \\
& linalool (2.2) \\
& 1,8 -cineole (49.9) \\
Alpinia calcarata & fenchylacetate (7.6) \\
& camphor (6.4) \\
& $\beta-$ pinene $(6.8)$ \\
& camphene (4.4) \\
\hline
\end{tabular}

* based on peak area

Contact toxicity of the four oils was compared at $15.0 \mathrm{\mu g} / \mathrm{cm}^{2}$ concentration (Table 3). The results revealed that C. zeylanicum has the highest mortality (100 $\%$ ) after $48 \mathrm{~h}$ of exposure. At a dose of $15.0 \mu \mathrm{g} / \mathrm{cm}^{2}$, C. nardus and C. citratus showed $70 \%$ and $46 \%$ mortality whereas A. calcarata oil did not show any contact toxic effect against $S$. oryzae at these concentrations. Based on $\mathrm{LC}_{50}$ values of the four essential oils, S. oryzae showed the highest susceptibility to C. zeylanicum oil. $\mathrm{LC}_{50}$ values for the essential oils of.C. citratus and C. nardus were not significantly different from each other ( $p>0.05)$. In contrast to contact toxicity and fumigant toxicity of essential oils tested, $S$. oryzae was highly susceptible for pirimiphos methyl (Table 4). 


\section{DISCUSSION}

The chemical constituents of the essential oils of $C$. citratus, $C$. nardus, $C$. zeylanicum and A. calcarata grown in Sri Lanka are similar to those reported previously. ${ }^{15,19,22}$

Table 2: Response of S. oryzae to essential oil treated and ethanol treated bottles during olfactometer bioassay.

\begin{tabular}{|c|c|c|c|c|c|}
\hline \multirow{2}{*}{\multicolumn{2}{|c|}{$\begin{array}{l}\text { Essential oil } \quad \text { Dose (mg) } \\
\text { (plant spp.) }\end{array}$}} & \multirow{2}{*}{\multicolumn{2}{|c|}{$\frac{\% \text { Response } \pm \text { S. E. }}{\text { EtOH treated }}$}} & \multirow[t]{2}{*}{$\sum_{1}^{2}$} & \multirow[t]{2}{*}{$P$ value } \\
\hline & & & & & \\
\hline \multirow[t]{5}{*}{ C. citratus } & 10 & $34 \pm 2.4$ & $34 \pm 10.2$ & 0 & $<0.05$ \\
\hline & 25 & $30 \pm 6.2$ & $38 \pm 3.5$ & 1.0 & $<0.05$ \\
\hline & 75 & $26 \pm 4.9$ & $58 \pm 7.1$ & $12.2^{* *}$ & $>0.05$ \\
\hline & 100 & $14 \pm 4.9$ & $78 \pm 4.4$ & $44.5^{* *}$ & $>0.05$ \\
\hline & 150 & $10 \pm 5.3$ & $74 \pm 10.7$ & $48.7^{* *}$ & $>0.05$ \\
\hline \multirow[t]{5}{*}{ C. nardus } & 0.5 & $28 \pm 5.8$ & $28 \pm 4.8$ & 0 & $<0.05$ \\
\hline & 1.0 & $28 \pm 1.9$ & $50 \pm 5.4$ & $6.2^{* *}$ & $>0.05$ \\
\hline & 2.5 & $14 \pm 6.7$ & $28 \pm 5.8$ & $4.6^{* *}$ & $>0.05$ \\
\hline & 5.0 & $12 \pm 1.9$ & $70 \pm 5.4$ & $41.0^{* *}$ & $>0.05$ \\
\hline & 7.5 & $5 \pm 2.5$ & $42 \pm 5.6$ & $29.1^{* *}$ & $>0.05$ \\
\hline \multirow[t]{5}{*}{ C. zeylanicum } & 1.0 & $40 \pm 0$ & $27 \pm 2.5$ & $13.3^{* * *}$ & $>0.05$ \\
\hline & 2.0 & $33 \pm 2.2$ & $25 \pm 5.7$ & 1.1 & $<0.05$ \\
\hline & 5.0 & $30 \pm 5.1$ & $42.5 \pm 9.2$ & 2.1 & $<0.05$ \\
\hline & 7.5 & $15 \pm 5.7$ & $55 \pm 5.7$ & $22.8^{* *}$ & $>0.05$ \\
\hline & 10.0 & $15 \pm 4.4$ & $55 \pm 5.7$ & $22.8^{* *}$ & $>0.05$ \\
\hline \multirow[t]{5}{*}{ A. calcarata } & 0.5 & $40 \pm 5.4$ & $42 \pm 3.7$ & 0 & $<0.05$ \\
\hline & 1.0 & $30 \pm 4.4$ & $44 \pm 3.9$ & 2.6 & $<0.05$ \\
\hline & 2.5 & $16 \pm 3.9$ & $56 \pm 7.4$ & $22.2^{* * *}$ & $>0.05$ \\
\hline & 5.0 & $14 \pm 4.9$ & $52 \pm 5.8$ & $21.8^{* *}$ & $>0.05$ \\
\hline & 7.5 & $12 \pm 1.9$ & $56 \pm 2.4$ & $28.4^{* *}$ & $>0.05$ \\
\hline
\end{tabular}

"p $<0.05,3.84 \quad * *$ significant at $5 \%$ (Chi square test)

$\S$ Ten insects were used in each replicate and mean of 5 replicates

In the olfactometer bioassay, S. oryzae showed a decrease in response with increasing dose of oil, except to C. zeylanicum oil at the dose of $1 \mathrm{mg}$. Eugenol, linalool, $\beta$-caryphyllene are some of the major constituents in $C$. zeylanicum leaf 
oil. ${ }^{15}$ Eugenol and linalool are behaviour modifying chemicals of many insects. ${ }^{24}$ This could be the reason for the possible attractant effect of $C$. zeylanicum oil at 1 mg. A two-choice test similar to the present study, was carried out with water extracts of Salvia officinalis, Artemisia absimthium, Sambucus nigra, Matricaria chamomilla and Anthum graveolous where less than $30 \%$ response was obtained for each extract at $15 \mathrm{~g}$ herbs/ $200 \mathrm{ml}$ water using $S$. granaries. ${ }^{2}$ Jembere et al. have demonstrated the repellent effect of Ocimum kilimandscharicum at $0.3 \mathrm{~g} /$ $250 \mathrm{~g}$ of wheat against $S$. zeamais. ${ }^{25}$ The essential oil of Evodia rutecarpa had a higher repellent effect to Tribolium castaneum than to $S$. zeamais during the treated repellency filter paper disc test. ${ }^{5}$

Table 3: Mortality of S. oryzae following the exposure to fumigant and contact effects of four essential oils.

\begin{tabular}{lcc}
\hline $\begin{array}{l}\text { Essential oil } \\
\text { (Plant spp.) }\end{array}$ & \multicolumn{2}{c}{$\%$ Mortality \pm S. E.* } \\
\cline { 2 - 3 } C. citratus & $100 \pm 0^{\mathrm{a}}$ & Contact $\left(15.0 \mu \mathrm{g} / \mathrm{cm}^{2}\right)$ \\
C. nardus & $65.0 \pm 6.7^{\mathrm{b}}$ & $46.0 \pm 12.8^{\mathrm{a}}$ \\
C. zeylanicum & $58.3 \pm 8.7^{\mathrm{b}}$ & $70.0 \pm 7.0^{\mathrm{b}}$ \\
A. calcarata & $8.3 \pm 3.0^{\mathrm{c}}$ & $100 \pm 0^{\mathrm{c}}$ \\
Control & $10.0 \pm 0.8^{\mathrm{c}}$ & $0^{\mathrm{d}}$ \\
Ethanol & $11.0 \pm 1.2^{\mathrm{c}}$ & $4.0 \pm 2.4^{\mathrm{e}}$ \\
\hline
\end{tabular}

"Mean of 5 replicates, means followed by similar letters within the column are not significantly different (ANOVA and Tukey's pair-wise comparison test)

Table 4: $\mathrm{LC}_{50}$ values of $S$. oryzae for fumigant and contact toxicity to four essential oils.

\begin{tabular}{lcc}
\hline \multirow{2}{*}{$\begin{array}{l}\text { Essential oil } \\
\text { (Plant spp.) }\end{array}$} & \multicolumn{2}{c}{$\mathrm{LC}_{50}$ value $^{*}$} \\
\cline { 2 - 3 } C. citratus & Fumigant $(\mathrm{mg} / \mathrm{l})$ & Contact $\left(\mu \mathrm{g} / \mathrm{cm}^{2}\right)$ \\
C. nardus & 35 & 11.5 \\
C. zeylanicum & 82 & 18.7 \\
A. calcarata & 70 & 3.6 \\
Pirimiphos methyl & $3.2 \times 10^{-1}$ & 40.0 \\
\hline
\end{tabular}

*48 hours exposure period 
According to the present study, essential oils of C. citratus and C. zeylanicum are the most potent fumigant and contact toxicant respectively. C. citratus oil contains linalool and linalyl acetate in addition to citral $a$ and $b$. It has been observed that monoterpene aldehydes have the highest fumigant effect against $T$. castaneum. ${ }^{26}$ Mentha citrata oil containing linalool and linalyl acetate has shown a significant fumigant effect to $S$. oryzae. ${ }^{27}$ Hence, it is likely that the high fumigant effect of essential oils of $C$. citratus could be due to the presence of citral $a$ and $b$, linalool and linalyl acetate. Eugenol, a phenyl propionoid, is the major constituent of $C$. zeylanicum leaf oil and topical application of phenols was more toxic to $T$. castaneum than other saturated alcohols. ${ }^{19,26}$ These findings are in agreement with the results obtained for the contact toxicity test in the present study.

S. oryzae adults were more tolerant to the fumigant and the contact effect of $A$. calcarata oil. The major constituent, 1,8-cineol, has been reported to have insecticidal properties against stored product beetles such as S. oryzae, Lasioderma serricorne (F.) and Stegobium paniceum (L.). The adults of T. castaneum were susceptible to both contact and fumigant toxicities of 1,8 -cineol and $\mathrm{LD}_{50}$ values of $108.4 \mu \mathrm{g} / \mathrm{mg}$ of body weight of adult insect and $1.52 \mu \mathrm{g} / 1$ air were obtained respectively. ${ }^{28}$ The low persistence rate and significant loss of toxicity of 1,8-cineol have also been observed..$^{29}$ Therefore, for the control of $S$. oryzae higher concentration of A. calcarata oil is required in toxicity assays. However, accumulation of high concentrations of terpenes in rice could affect the quality of the grain and their consumption. ${ }^{30}$

Contact and fumigant toxicities of essential oils to stored product beetles have been studied extensively. Cinnamaldehyde, the main constituent of cinnamon bark oil had similar fumigant and contact toxic effects on both $T$. castaneum and S. zeamais. ${ }^{31}$ Cardamom and nutmeg oils were generally more effective contact poisons and fumigants against adults of $S$. zeamais than those of $T$. castaneum. ${ }^{6,7}$ The toxicity and ovicidal activity of $C$. nardus oil were tested against adults and the eggs of Callasobruchus maculatus and the eggs were more susceptible to the test oil than the adults. ${ }^{17}$

In the present study, $\mathrm{LC}_{50}$ values for pirimiphos methyl were determined for $S$. oryzae during fumigant and contact toxicity assays. The results indicated that pirimiphos methyl is more effective than the essential oils tested. However, in view of the mammalian toxicity and development of environmental friendly products, these essential oils will still be prefered.

The present study on the biological activity of tested essential oils revealed the potential of the essential oils as a pest control agent of stored grain. The essential oils of $C$. citratus and C. zeylanicum showed the highest potential to be used as a fumigant and as a contact toxicant. $C$. nardus gave the highest repellent activity. Hence, these studies suggest that $C$. citratus, C. nardus, C. zeylanicum and $A$. 
calcarata oils could be developed as potential grain protectants against adults of $S$. oryzae. However, there is a need to asses the cost-effectiveness and feasibility of using these essential oils on a large scale as grain protectants. Isolation and identification of effective compounds from the essential oils having toxic properties is necessary before considering the commercial application.

\section{Acknowledgements}

Authors gratefully acknowledge the financial assistance provided by the National Science Foundation, National Research Council, Sri Lanka and the Third World Academy of Science. The assistance of Dr. U. Chandrasekera of University of Kelaniya in statistical analysis and the technical staff of Departments of Chemistry and Botany of Kelaniya University and Rice Research and Development Institute of Bathalagoda are acknowledged.

\section{Reference}

1 Chapman B. R. \& Dyte C. E. (1976). Report of the FAO global survey of pesticide susceptibility of stored grain pests. FAO Plant Production and Protection Series no.5. FAO of the United Nations, Rome. pp 1-99.

2 Ignatowicz S. \& Wesolowska B. (1994). Potential of common herbs as grain protectants: repellent effect of grain extracts on granary weevils, Sitophilus granarius L. pp790-794. In: Proceedings of the $6^{\text {th }}$ International Working Conference on stored product protection.(Eds. E. Highley, E. J. Wright, H. J. Banks \& B. R. Chapman)

3 Best G. A. \& Ruthven A. D. (1995). Pesticides- developments, impacts and controls. Royal Society of Chemistry, UK.

4 Don-Pedro K. N. (1996). Fumigant toxicity is the major rout of insecticidal activity of citrus peel essential oils. Pesticide Science 46: 71-78.

5 Liu Z. L. \& Ho S. H. (1999). Bioactivity of the essential oil extracted from Evodia rutaecarpa Hook f. et Thomas against the grain storage insects, Sitophilus zeamais Motsch. and Tribolium castaneum (Herbst). Journal of Stored Product Research 35: 317-328.

6 Huang Y., Lam S. L. \& Ho S. H. (2000). Bioactivities of essential oil from Elletaria cardamomum (L.) Maton. to Sitophilus zeamais Motsch. and Tribolium castaneum (Herbst). Journal of Stored Product Research 36:107117. 
7 Huang Y., Tan J. M. W. L., Kini R. M. \& Ho H. (1997). Toxic and antifeedent action of nutmeg oil against Tribolium castaneum (Herbst.) and Sitophilus zeamais Motsch. Journal of Stored Product Research 33(4): 289 - 298.

8 Xie S. Y., Fields P. G., Isman M. B., Chen K. W. \& Zhang X. (1995). Insecticidal activity of Melia toosendan extracts and Toosendanin against three storedproduct insects. Journal of Stored Product Research 31: 259-265.

9 Ahmed S. \& Grainge M. (1986). Potential of the Neem tree (Azadirachta indica) for pest control and rural development. Economic Botany 40(2): 201209.

10 Jilani G. \& Su C. F. H. (1983). Laboratory studies on several plant materials as insect repellents for protection of cereal grains. Journal of Entomological Society of America 76: 1111-1115.

11 Swarnasiri D. P. C. \& Palipane K. B. (1995). Use of plant material for insect control in farm level grain storage. RPRDC Technical Report No. 33/95, Rice Processing, Research and Development Centre, Paddy Marketing Board, Anuradhapura, Sri Lanka. pp 1-8.

12 Shaaya E., Kostjukovski M., Eilberg J. \& Sukprakarn C. (1997). Plant oils as fumigants and contact insecticides for the control of stored-product insects. Journal of Stored Product Research 33: 7-15.

13 Nethsingha C. \& Paskaranathan U. (1976). Lemongrass- A literature survey. Spice and essential oil bearing plants, no. 3. Ceylon Institute of Scientific and Industrial Research, Colombo, Sri Lanka.

14 Rajapakse R. \& Van Emden H. F. (1997). Potential of four vegetable oils and ten botanical powders for reducing infestation of cowpeas by Callosobruchus maculatus, C. chinensis and C. rhodesianus. Journal of Stored Product Research 33(1): 59-68.

15 Paranagama P. A. (1991). Analysis of Sri Lankan essential oils by gas chromatography and mass spectroscopy. (Ed. U. M. Senanayake) Industrial Technology Institute, Colombo, Sri Lanka. 40p.

16 Jayasinghe P., Warnasuriya D. \& Dissanayaka H. (1999). Citronella, Medicinal and aromatic plant series, No. 8. Industrial Technology Institute, Sri Lanka pp. 14-15.

17 Ketoh G. K., Glitho A. I. \& Huignard J. (2002). Susceptibility of the bruchid Callosobruchus maculatus (Coleoptera: Bruchidae) and its parasitoid 
Dinarmus basalis (Hymenoptera: Pteromalidae) to three essential oils. Journal of Economic Entomology 95(1): 174-182.

18 Adhikari A. A. C. K., Paranagama P. A., Abeywickrama K. P. \& Premarathne Bandara K. A. N. P. (2002). Behavioural studies of cowpea bruchid Callasobruchus maculatus (F.) against volatile extracts from leaves of lemongrass, neem and curry leaves. Tropical Agricultural Research 14: 138147.

19 Paranagama P. A., Wimalasena S., Jayatilake G. S., Jayawardena A. L., Senanayake U. M. \& Mubarak A. M. (2001). A comparison of essential oil constituents of bark, leaf, root and fruit of cinnamom (Cinnamomum zeylanicum Blume) grown in Sri Lanka. Journal of the National Science Foundation Sri Lanka 29(3\&4): 147-153.

20 Huang Y., Ho S. H., Lee H. C. \& Yap Y. L. (2002). Insecticidal properties of eugenol, isoeugenol and methyleugenol and their effects on Sitophilus zeamais (Coleoptera: Curculionidae) and Tribolium castaneum (Coleoptera: Tenebrionidae). Journal of Stored Product Research 38(5): 403 - 412.

21 Tewari A., Pant A. K., Mathela C. S., Mangi N., Khol E. \& Bestman S. J. (1999). Volatile constituents of Alpinia calcarata Rosc. Journal of Essential Oil Research 11: 739-741.

22 Ekanayaka E. M. D. S. \& Paranagama P. A. (1999). Repellent activity of Alpinia calcarata volatiles for Periplanata americana. Proceedings of $55^{\text {th }}$ annual sessions of Sri Lanka Association for the Advancement of Science, E202.

23 Bandara K. A. N. P. (1997). Insecticidal components from some Sri Lankan plants. Ph. D. Thesis, University of Peradeniya, Sri Lanka.

24 Bedoukian R. H. (1992). Regulation of some class of phytochemicals: flavor and fragrance ingredients related to insect behavior-modifying chemicals. pp. 79-82. In: Insect pheromone and other behavior modifying chemicals Monograph No. 51. (Eds. R. L. Ridgway, M. Inscoe \& H. Arn) British Crop Protection Council, Surrey, U.K. pp. 79-82.

25 Jembere B., Obeng Ofori D., Hassanali A. \& Nyamasyo G. N. N. (1995). Products derived from the leaves of Ocimum kilimandscharicum (Labiatae) as post-harvest grain protectants against infestation of three major stored product insect pests. Bulletin of Entomological Research 85: 361-367. 
26 Rice P. J. \& Coats R. J. (1994). Insecticidal properties of several monoterpenoids to the house fly (Diptera: Muscidae), red flour beetle (Coleoptera: Tenebrionidae), and southern corn root worm (Coleoptera: Chrysomelidae). Journal of Economic Entomology 87(5): 1172-1179.

27 Singh D., Siddiqui M. S. \& Sharma S. (1989). Reproductive retardant and fumigant properties in essential oil against rice weevil Sitophilus oryzae (Coleoptera: Curculionidae) in stored wheat. Journal of Economic Entomology 82:727-733.

28 Tripathi A. K., Rajapati V., Aggrawal K. K., Khanuja S. P. S. \& Kumar S. (2000). Repellency and toxicity of oil from Artemisia annua to certain storedproduct beetles. Journal of Economic Entomology 93(1): 43-47.

29 Obeng-Ofori D. \& Reichmuth C. H. (1999). Plant oils as potential agents of monoterpenes for protection of stored grains against damage by stored product beetle pests. International Journal of Pest Management 45(2): 155-159.

30 Goubran F.H. \& Holmes R.J. (1997). Natural alternatives for the control of postharvest rots in citrus. Institute for Horticultural Development, Department of Agriculture, Victoria, Australia.

31 Huang Y. \& Ho S. H. (1998). Toxicity and antifeedent activities of cinnamaldehyde against the grain storage insects, Tribolium castaneum (Herbst.) and Sitophilus zeamais Motsch. Journal of Stored Product Research 34(1):11-17. 